\title{
HUBUNGAN ANTARA FAKTOR INTERNAL DAN EKSTERNAL KELUARGA BURUH MIGRAN DENGAN KESEDIAAN UNTUK BERINVESTASI
}

\author{
THE RELATIONSHIP BETWEEN FAMILY INTERNAL AND EXTERNAL \\ FACTORS WITH WILLIGNESS TO INVEST OF IMIGRANT LABOUR'S
}

\author{
Rina Damayanti Wulansari ${ }^{1}$, Georgius Hartono², Rukmadi Warsito
}

Diterima 14 Maret 2014, disetujui 28 Mei 2014

\begin{abstract}
The purposes of this study are to determine: 1) the relationship between internal as well as external factors of Indonesian migrant workers' family and their willingness to invest, 2) the types of investment made and the obstacles encountered, and 3) the amount of remittances received. The research was conducted in Pabelan and Tuntang Districts Semarang Regency by using explanatory research with quantitative and qualitative analyses approach. Data obtained from 80 respondents in earlier study entitled "Indonesian Labour Force: Roles and Impacht ono Rural Economy Central Jawa Province (2nd year)" and interviews with re-using 12 sampel of respondent. Spearman rank corelation and paired T-test at the confidence level of 95 percent were used to determine the magnitude of the relationship among assessed variables.
\end{abstract}

Results of this study indicate that the internal and external factors of migrant labors' family were strongly related to their willingness to invest. The types of investment were building a firm and buying land, cars, cattle or house. Saving money and purchasing motorcycle were considered the combination of investment and consumptive goods, and household variable are buying consumer goods for labour's families migrant. The barriers were faced by families of migrant labours, there was the urgency of daily life needs, house improvements, school fees, labour's departure-related costs and other debts. The amount of remittances associated with the willingness to invest is different among migrant labors working in varied countries. This is resulted from the different wages standard of each country of destination, labor's departure fee discount, the working period, and the types of jobs abroad.

Keywords: family internal factor, family external factor, remittance, imigrant labour

\section{PENDAHULUAN}

Perpindahan dari suatu negara ke negara lain yang biasa disebut sebagai migrasi menjadi sebuah fenomena yang terjadi di beberapa negara berkembang. Indonesia merupakan salah satu negara yang tidak dapat melepaskan diri dari dinamika tersebut, sehingga pengiriman pekerja migran ke luar negeri berdampak signifikan pada perekonomian masyarakat (Subianto, 2006: 1). Migrasi ini terutama dilatar belakangi oleh faktor ekonomi. Para migran bertujuan untuk mencari penghidupan yang lebih layak daripada di negara asal mereka. Hal ini didukung dengan kurang tersedianya lapangan kerja sesuai dengan kemampuan yang dimiliki, kurangnya ketrampilan yang dimiliki seseorang untuk dapat membuka usaha sendiri dan banyaknya pemutusan hubungan kerja

\footnotetext{
${ }^{1}$ Alumni Fakultas Pertanian dan Bisnis Universitas Kristen Satya Wacana.

${ }^{2}$ Staff Pengajar Program Studi Agribisnis, Fakultas Pertanian dan Bisnis Universitas Kristen Satya Wacana email: g.hartono@staff.uksw.edu
} 
(PHK) seseorang. Faktor penarik seseorang menjadi buruh migran yaitu gaji atau intensif yang lebih menarik atau tinggi daripada negara asal (Primasanto, 2010: 187-188). Kebanyakan yang menjadi buruh migran adalah masyarakat pedesaan yang dipicu oleh sempitnya lapangan pekerjaan di desa dan tawaran tentang tingginya pendapatan yang diperoleh jika bekerja di luar negeri daripada bekerja di desanya sendiri.

Pendapatan digunakan oleh setiap rumah tangga dengan tujuan untuk memenuhi kebutuhan rumah tangga (Sukirno, 1994). Pendapatan juga bertujuan untuk disimpan atau ditabung untuk memperoleh bunga atau dana yang digunakan untuk menghadapi kemungkinanan kesulitan di masa yang akan datang. Selain untuk ditabung, pendapatan juga digunakan untuk berinvestasi. Menurut Halim (2009) dalam konsep time value of money, kebanyakan orang lebih senang untuk menikmati uang yang tersedia sekarang daripada jumlah uang yang sama, namun tersedia setahun mendatang. Sedangkan ada orang yang senang untuk tidak menikmati sejumlah uang sekarang melainkan menundanya untuk menikmati setahun kemudian jika uang yang tersedia lebih besar.

Dalam hal ini, remitan atau uang kiriman dari hasil bekerja sebagai buruh migran di luar negeri dapat dinikmati secara bijaksana dan lebih lama dengan memanfaatkannya untuk berinvestasi. Hal ini terkait dengan karakterisitik rumah tangga yakni pendidikan, usia, jenis kelamin, jumlah tanggungan keluarga dan persepsi kondisi atau fasilitas lingkungan yang berhubungan dengan kesediaan berinvestasi.

Mengacu latar belakang masalah yang telah diuraikan tersebut, maka penelitian ini bertujuan mengetahui hubungan antara faktor internal dan eksternal keluarga buruh migran dengan kesediaan untuk berinvestasi, mengetahui macam investasi yang dilakukan dan hambatan untuk berinvestasi, dan mengetahui besarnya remitan buruh migran.

\section{METODE PENELITIAN}

Penelitian dilaksanakan di Kecamatan Pabelan dan Kecamatan Tuntang, karena di dua kecamatan tersebut banyak keluarga yang salah satu atau lebih anggota keluarganya menjadi buruh migran. Jenis penelitian yang digunakan adalah penelitian eksplanatori, dengan menggunakan pendekatan analisis kuantitatif dan kualitatif. Penggambaran populasi yakni sistem ekonomi pedesaan atau rakyat yang terimbas uang remitan dari buruh migran asal Kabupaten Semarang dan sampel adalah sejumlah wilayah yang terimbas uang remitan. Informasi dan permasalahan penelitian dilakukan penelitian survey. Pengambilan contoh digunakan "Step Cluster Sampling" atau pengambilan gugus bertahap yaitu Kecamatan, Kelurahan, Desa dan Responden. Data 80 responden yang diperoleh dari penelitian berjudul "Tenaga Kerja Indonesia (TKI) Peran dan Pengaruhnya Terhadap Ekonomi Rakyat di Wilayah Pedesaan Provinsi Jawa Tengah (Mencari Pola Pembinaan Investasi Tahun ke2" dengan observasi dan wawancara ulang menggunakan 12 sampel reponden. Alat analisis korelasi menggunakan rank spearman, dan untuk mengetahui besarnya hubungan antar variabel menggunakan uji $\mathrm{T}$ (paired T-test) tingkat kepercayaan 95 persen uji 2 arah.

\section{HASIL DAN PEMBAHASAN}

\section{Hubungan Faktor Internal dengan Kesedia- an Berinvestasi}

Dalam analisis hubungan faktor internal keluarga buruh migran dengan kesediaan untuk berinvestasi, terdapat beberapa variabel yang signifikan. Variabel untuk faktor internal yaitu pendidikan kepala keluarga (KK) dan buruh migran, usia KK dan buruh migran, jumlah anggota keluarga. Nilai koefisien rank Spearman (rs) yang diperoleh dari hasil komputasi dapat diikuti pada Tabel 1. 
Tabel 1. Hubungan Antara Faktor Internal dengan Kesediaan untuk Berinvestasi

\begin{tabular}{lccc}
\hline \multicolumn{1}{c}{ Variabel } & $\begin{array}{c}\text { Koefisien Rank } \\
\text { Spearman (rs) }\end{array}$ & T-hitung & $\begin{array}{c}\text { T-Tabel } \\
\text { (Tingkat kepercayaan 95\%) }\end{array}$ \\
\hline Pendidikan KK & 0,022 & 24,431 & 1,990 \\
Pendidikan Buruh Migran & $-0,039$ & $-22,993$ & 1,990 \\
Usia KK & 0,214 & 27,868 & 1,990 \\
Usia Buruh Migran & 0,336 & 30,170 & 1,990 \\
Jumlah Anggota Keluarga & 0,133 & 13,699 & 1,990 \\
\hline
\end{tabular}

Keterangan: Tingkat Kepercayaan $=95 \%, \mathrm{t}(0,025)=1,990, \mathrm{n}=80,2$ Arah

Sumber: Analisis Data Primer (2012)

Dari Tabel 1 dapat dilihat semua variabel faktor internal mempuyai nilai t-hitung > t-Tabel. Hal ini membuktikan bahwa semua variabel dari faktor internal signifikan dengan tingkat kepercayaan 95 persen.

Berdasarkan Tabel 1 nilai koefisien rank Spearman (rs) untuk variabel pendidikan KK $(0,022)$, usia KK $(0,214)$, usia buruh migran $(0,336)$ dan jumlah anggota keluarga $(0,133)$ artinya keempat variabel mempunyai hubungan dengan kesediaan untuk berinvestasi dengan arah hubungan bersifat positif. Sedangkan nilai koefisien rank Spearman (rs) untuk variabel pendidikan buruh migran $(-0,039)$ artinya variabel tersebut mempunyai hubungan dengan kesediaan untuk berinvestasi dengan arah hubungan bersifat negatif.

\section{a. Hubungan antara Pendidikan KK dan Pen- didikan Buruh Migran dengan Kesediaan Berinvestasi}

Berdasarkan Tabel 1 hubungan antara pendidikan KK dan pendidikan buruh migran dengan kesediaan berinvestasi mempunyai nilai t-hitung sebesar 24,431 dan -22,993 yang lebih besar dari t-Tabel sebesar 1,990 artinya terdapat hubungan signifikan dengan tingkat kepercayaan 95 persen. Nilai koefisien RS pendidikan adalah positif dan pendidikan buruh migran adalah negatif, hal ini menyatakan semakin tinggi pendidikan KK maka semakin tinggi kesediaan untuk berinvestasi, dan semakin tinggi pendidikan buruh migran maka akan semakin rendah kesediaan untuk berinvestasi.
Hubungan yang signifikan dikarenakan seorang KK dengan pendidikan tinggi lebih mengutamakan uang remitan untuk membuat usaha baru dan membeli tanah untuk bercocok tanam. Dengan membuka usaha baru, uang remitan yang diperoleh dapat dinikmati lebih lama dengan melakukan perputaran uang dari usaha yang diciptakan, sedangkan membeli tanah dapat digunakan untuk bercocok tanam atau disewakan sebagai lahan garapan. Lain halnya dengan seorang KK dengan pendidikan rendah akan lebih mengutamakan untuk pemenuhan kebutuhan yang dianggap konsumtif daripada untuk berinvestasi yang harus menunggu waktu lama dalam menikmatinya.

Seorang buruh migran dengan pendidikan tinggi akan lebih mengutamakan pendapatan atau uang remitan yang diperoleh untuk pendidikan anakanaknya. Buruh migran dengan pendidikan yang tinggi selalu menginginkan anak-anaknya untuk dapat menjadi orang sukses dengan memperoleh pendidikan yang layak dan setinggi-tingginya, agar tidak bernasib sama dengan orang tua mereka. Lain halnya dengan seorang buruh migran dengan pendidikan rendah akan memilih untuk berinvestasi sebanyak-banyaknya. Dikarenakan setelah anggota keluarga yang menjadi buruh migran atau buruh migran itu sendiri tidak lagi bekerja di Luar Negeri, dapat tetap menikmati hasil kerja kerasnya lebih lama bahkan jika mempunyai berinvestasi tanah dapat diwariskan ke anak cucu mereka nantinya. 


\section{b. Hubungan antara Usia KK dan Buruh Migran dengan Kesediaan Berinvestasi}

Berdasarkan Tabel 1 hubungan antara usia KK dan usia buruh migran dengan kesediaan berinvestasi mempunyai nilai t-hitung sebesar 27,868 dan 30,170 yang lebih besar dari t-Tabel sebesar 1,990 artinya terdapat hubungan yang signifikan dengan tingkat kepercayaan 95 persen. Angka yang positif menunjukkan semakin tinggi usia KK dan buruh migran maka semakin tinggi kesediaan untuk berinvestasi, sebaliknya semakin rendah usia KK dan buruh migran maka semakin rendah kesediaan untuk berinvestasi.

Hubungan yang signifikan ini dikerenakan semakin tinggi usia seorang KK dan buruh migran akan lebih mengutamakan untuk berinvestasi agar dapat dinikmati lebih lama, seperti membeli tanah, ternak dan membuka usaha karena investasi semacam ini dianggap dapat mencukupi kelangsungan hidup keluarga jika anggota keluarga yang menjadi buruh migran atau buruh migran itu sendiri tidak lagi bekerja di Luar Negeri dan dapat bertahan lama dan bertambah. Lain halnya jika beberapa KK dan buruh migran yang baru saja menikah atau masih mempunyai anak yang masih menjadi tanggungan, sehingga uang remitan yang diperoleh kebanyakan digunakan untuk perbaikan rumah, pemenuhan kebutuhan seharihari dan membiayai pendidikan anak-anak mereka.

\section{c. Hubungan antara Jumlah Anggota Keluarga dengan Kesediaan Berinvestasi}

Berdasarkan Tabel 1 hubungan antara jumlah anggota keluarga dengan kesediaan berinvestasi mempunyai nilai t-hitung $(13,699)>\mathrm{t}$-Tabel $(1,990)$ artinya terdapat hubungan yang signifikan dengan tingkat kepercayaan 95 persen. Dari hasil komputasi yang dilakukan, nilai koefisien (rs) jumlah anggota keluarga dengan kesediaan untuk berinvestasi didapatkan nilai 0,133. Hasil ini menyatakan antara jumlah anggota keluarga dengan kesediaan untuk berinvestasi terdapat hubungan bersifat positif. Artinya semakin sedikit jumlah anggota keluarga maka semakin rendah kesediaan untuk berinvestasi, sebaliknya semakin banyak jumlah anggota keluarga maka semakin tinggi kesediaan untuk berinvestasi.

Hubungan yang signifikan ini dikarenakan banyaknya anggota keluarga maka memicu untuk membuka usaha baru. Selain remitan dari buruh migran dapat berputar bahkan bertambah, membuka usaha baru nantinya dapat diwariskan anggota keluarga atau dapat dikelola turun temurun. Lain halnya dengan jumlah anggota keluarga yang sedikit akan menggunakan uang remitan untuk biaya pendidikan anak-anaknya dan pemenuhan kebutuhan harian yang bersifat konsumtif.

\section{Hubungan Faktor Eksternal dengan Kesediaan untuk Berinvestasi}

Faktor eksternal yang dianalisis meliputi persepsi keluarga buruh migrant terhadap fasilitas umum yaitu, fasilitas jalan dan angkutan, fasilitas komunikasi, fasilitas pendidikan, dan kesuburan tanah. Hasil komputasinya dapat diikuti dalam Tabel 2.

Dalam Tabel 2 terlihat bahwa semua variabel faktor eksternal terdapat nilai t-hitung > t-Tabel. Hal ini membuktikan semua variabel dari faktor eksternal signifikan dengan tingkat kepercayaan 95 persen. Nilai koefisien rank Spearman (rs) untuk variabel fasilitas jalan dan angkutan $(-0,303)$ artinya variabel tersebut mempunyai hubungan dengan kesediaan berinvestasi dengan arah hubungan negatif. Sedangkan nilai koefisien rank Spearman (rs) variabel fasilitas komunikasi $(1,000)$, fasilitas pendidikan $(0,726)$, dan kesuburan tanah $(0,686)$ yang artinya masing-masing variabel mempunyai hubungan dengan kesediaan untuk berinvestasi dengan arah hubungan bersifat positif.

\section{a. Persepsi Keluarga Buruh Migran terhadap Fasilitas Jalan dan Angkutan}

Berdasarkan Tabel 2 hubungan antara persepsi keluarga buruh migrant terhadap fasilitas jalan dan 
angkutan dengan kesediaan berinvestasi mempunyai nilai t-hitung $(-23,494)>\mathrm{t}$-Tabel $(1,990)$ artinya terdapat hubungan yang signifikan dengan tingkat kepercayaan 95 persen. Dari hasil komputasi yang dilakukan, nilai rs nya $-0,303$. Hasil ini menyatakan bahwa antara fasilitas jalan dan angkutan dengan kesediaan untuk berinvestasi terdapat hubungan bersifat negatif. Artinya semakin baik fasilitas jalan dan angkutan maka semakin rendah kesediaan untuk berinvestasi, sebaliknya semakin buruk fasilitas jalan dan angkutan maka semakin tinggi kesediaan untuk berinvestasi.

Hubungan yang signifikan ini dikarenakan orang akan lebih memanfaatkan fasilitas jalan dan angkutan yang baik dengan cara menggunakan angkutan untuk pergi ketempat tujuan dengan fasilitas jalan yang baik pula untuk berbagai kepentingan. Dengan demikian uang remitan yang didapatkan lebih banyak dipakai untuk bepergian dan hanya tersisa sedikit yang dapat digunakan untuk berinvestasi.

\section{b. Persepsi Keluarga Buruh Migran terhadap Fasilitas Komunikasi}

Berdasarkan Tabel 2 hubungan antara fasilitas komunikasi dengan kesediaan berinvestasi mempunyai nilai t-hitung $(24,243)>t$-Tabel $(1,990)$ artinya terdapat hubungan yang signifikan dengan tingkat kepercayaan 95 persen. Dari hasil komputasi yang dilakukan, nilai koefisien (rs) fasilitas komunikasi dengan kesediaan untuk berinvestasi didapatkan nilai 1,000. Hasil ini menyatakan antara fasilitas komunikasi dengan kesediaan untuk berinvestasi terdapat hubungan bersifat positif. Artinya semakin baik fasilitas komunikasi maka semakin tinggi kesediaan untuk berinvestasi, sebaliknya semakin buruk fasilitas komunikasi maka semakin rendah kesediaan untuk berinvestasi.

Hubungan yang signifikan ini dikarenakan seseorang akan lebih mudah mendapatkan informasi tentang peluang usaha yang memungkinkan untuk dimasukinya yang dilihat dari beberapa aspek yang dianggapnya penting seperti biaya investasi, tingkat teknologi yang diperlukan, tingkat pengembalian modal dan tingkat keuntungan yang dapat dicapai. Dengan semakin mudahnya orang untuk mendapatkan informasi yang tepat, akurat, maka orang tersebut akan lebih mudah dalam membuat perencanaan investasi yang diinginkan, yang tentunya orang tersebut akan merasa lebih terjamin bahwa nantinya investasi yang direncanakan akan memberi hasil yang memuaskan.

\section{c. Persepsi Keluarga Buruh Migran terhadap Fasilitas Pendidikan}

Berdasarkan Tabel 2 hubungan antara persepsi keluarga buruh migran terhadap fasilitas pendidikan dengan kesediaan berinvestasi mempunyai nilai t-hitung $(24,191)>$ t-Tabel $(1,990)$ artinya terdapat hubungan yang signifikan dengan tingkat kepercayaan 95 persen. Dari hasil komputasi yang dilakukan, nilai rs sebesar 0,726 . Hasil ini menyatakan antara fasilitas pendidikan dengan kesediaan untuk berinvestasi terdapat hubungan bersifat positif. Artinya semakin baik

Tabel 2. Hubungan Antara Faktor Eksternal dengan Kesediaan untuk Berinvestasi

\begin{tabular}{lccc}
\hline \multicolumn{1}{c}{ Variabel } & $\begin{array}{c}\text { Koefisien Rank } \\
\text { Spearman (rs) }\end{array}$ & T-hitung & $\begin{array}{c}\text { T-Tabel } \\
\text { (Tingkat kepercayaan 95\%) }\end{array}$ \\
\hline Fasilitas Jalan dan Angkutan & $-0,303$ & $-23,494$ & 1,990 \\
Fasilitas Komunikasi & 1,000 & 24,243 & 1,990 \\
Fasilitas Pendidikan & 0,726 & 24,191 & 1,990 \\
Kesuburan Tanah & 0,686 & 24,483 & 1,990 \\
\hline
\end{tabular}

Keterangan: Tingkat Kepercayaan $=95 \%, \mathrm{t}(0,025)=1,990, \mathrm{n}=80,2$ Arah

Sumber: Analisis Data Primer (2012) 
fasilitas pendidikan maka semakin tinggi kesediaan untuk berinvestasi, sebaliknya semakin buruk fasilitas pendidikan maka semakin rendah kesediaan untuk berinvestasi.

Hubungan yang signifikan ini dikarenakan dengan adanya persepsi keluarga buruh migran terhadap fasilitas pendidikan yang baik, lengkapnya tempat pendidikan dari TK sampai dengan Universitas, maka seseorang terpicu untuk berinvestasi, dan memicu seseorang menggunakan uang remitan untuk membuka usaha baru seperti warung makan, toko alat tulis dan fotocopy, yang tentunya aka ada pembeli dari tempat-tempat pendidikan tersebut, sehingga hasil yang didapat dapat berkembang dan dinikmati lebih lama. Lain halnya bagi keluarga yang persepsinya terhadap fasilitas pendidikan buruk maka akan memicu seseorang untuk membeli barang-barang konsumtif dan tidak menggunakannya untuk berinvestasi.

\section{d. Persepsi Keluarga Buruh Migran terhadap Kesuburan Tanah}

Berdasarkan Tabel 2 hubungan antara persepsi keluarga buruh migran terhadap kesuburan tanah dengan kesediaan berinvestasi mempunyai nilai t-hitung $(24,483)>$ t-Tabel $(1,990)$ artinya terdapat hubungan yang signifikan. Dari hasil komputasi yang dilakukan, nilai rs nya sebesar 0,686 . Hasil ini menyatakan bahwa antara kesuburan tanah dengan kesediaan untuk ber- investasi terdapat hubungan bersifat positif. Artinya semakin baik kesuburan tanah maka semakin tinggi kesediaan untuk berinvestasi, sebaliknya semakin buruk kesuburan tanah maka semakin rendah kesediaan untuk berinvestasi.

Hubungan yang signifikan ini dikarenakan orang yang sudah mempunyai tanah sebelum dirinya atau anggota keluarga bekerja sebagai buruh migran, akan terus memanfaatkan tanahnya untuk bercocok tanam dan meningkatkan penggunaan sarana produksi bila mereka mempunyai persepsi bahwa tingkat kesuburan tanah di desanya baik. Apabila memungkinkan mereka akan menyewa atau bahkan membeli tanah lagi untuk ditanami. Ini semua merupakan salah satu bentuk investasi yang mereka lakukan.

\section{Jenis dan Hambatan Berinvestasi}

Terdapat beberapa macam investasi yang banyak dilakukan oleh keluarga buruh migran. Macam investasi yang dilakukan adalah buka usaha, beli tanah, beli mobil, beli speda motor, beli rumah, beli ternak. Sebagian responden menyatakan bahwa macam tabungan uang, dan beli motor termasuk sebagai fungsi gabungan antara macam investasi dan barang konsumtif. Data jenis investasi yang dilakukan buruh migran dapat diikuti dalam Tabel 3.

Tabel 3. Macam Investasi yang Dilakukan

\begin{tabular}{lcc}
\hline Macam Investasi & $\begin{array}{c}\text { Jumlah responden } \\
\text { yang menyatakan } \\
\text { (orang) }\end{array}$ & $\begin{array}{c}\text { Persentase } \\
(\%)\end{array}$ \\
\hline Tabungan Uang & 35 & 44 \\
Usaha & 17 & 21 \\
Beli Tanah & 22 & 28 \\
Beli Mobil & 5 & 6 \\
Beli Motor & 41 & 51 \\
Beli Rumah & 6 & 8 \\
Beli Ternak & 4 & 5 \\
\hline JUMLAH & 80 & \\
\hline
\end{tabular}

Sumber: Analisis Data Primer (2012) 
Berdasarkan hasil re-check membuka usaha baru menjadi salah satu cara untuk dapat menikmati uang remitan lebih bijaksana dan lebih lama, selain itu juga dapat membuka lapangan pekerjaan bagi tetangga sekitar yang membutuhkan pekerjaan. Penanaman investasi dalam bentuk tanah ditujukan agar dapat disewakan untuk bercocok tanam atau digunakan sendiri untuk menanam padi dan palawija yang kemudian dapat dijual ke pasar. Investasi dalam bentuk mobil ditujukan untuk mengangkut barang dagangan dan disewakan untuk usaha rental mobil. Investasi dalam bentuk ternak besar seperti sapi dan kerbau digunakan untuk pengolah lahan sawah dan tabungan. Investasi rumah dimaksudkan untuk diwariskan kepada anak cucu, selain itu untuk jangka pendeknya, jika membeli rumah dapat dikontrakkan dan memperoleh uang tambahan dari hasil sewa rumah bentuk. Investasi dalam bentuk uang tabungan di bank dimaksudkan agar uang remitannya tersimpan aman, terkontrol dalam pemakaian uang yang seperlunya dan mendapatkan bunga, serta digunakan sebagai tambahan modal usaha dan biaya pendidikan anak. Investasi dalam bentuk sepeda motor dimaksudkan sebagai alat transportasi untuk mempermudah bepergian letak tempat tinggal yang jauh dari jangkauan angkutan umum dengan kondisi jalan yang kurang baik, juga untuk mengangkut hasil panen ke gudang dan ke pasar.

Kebanyakan responden menyatakan bahwa hambatan berinvestasi merupakan persoalan yang dihadapi ketika anggota keluarganya yang menjadi buruh belum berangkat ke luar negeri dan kadang-kadang menjadi alasan yang mendorong keberangkatannya. Selama persoalan utama yang dihadapi belum terselesaikan, maka uang remitan yang diperoleh tentunya akan dipakai untuk menyelesaikan persoalan tersebut, sehingga mereka tidak dapat berinvestasi. Biasanya persoalan yang dihadapi lebih dari satu macam. Hambatan berinvestasi yang paling banyak dinyatakan responden adalah kebutuhan hidup harian yang belum tercukupi yang dinyatakan oleh 76 orang atau 95 persen, rumah tinggal yang tidak layak huni sehingga perlu direhab yang dinyatakan oleh 66 orang atau 83 persen dan kesulitan pembiayaan sekolah untuk anak yang dinyatakan oleh 51 orang atau 64 persen. Data tetang hambatan berinvestasi selengkapnya dapat diikuti dalam Tabel 4.

\section{Besarnya Remitan Buruh Migran}

Besarnya remitan yang didapat oleh buruh migran dipengaruhi oleh negara tujuan, jenis pekerjaan/tingkat gaji yang diterima, pemberian gaji tambahan dari majikan dan kemampuan orang untuk menyisihkan gajinya di negeri orang. Ada buruh migran yang gajinya tinggi, namun dia tidak mampu menahan diri dalam menggunakan gajinya, maka remitan yang dapat dikirimkan kepada keluarganya tidak banyak. Dalam Tabel 5, ditunjukkan bahwa total kirim uang remitan berbeda-beda dari 6 negara tujuan yaitu Arab Saudi, Singapura, Taiwan, Malaysia, Kuwait, Korea.

Tabel 4 Hambatan untuk Berinvestasi

\begin{tabular}{lcc}
\hline \multicolumn{1}{c}{ Jenis hambatan } & $\begin{array}{c}\text { Jumlah responden } \\
\text { Yang menyatakan } \\
\text { (orang) }\end{array}$ & $(\%)$ \\
\hline Perbaikan atau Rehab Rumah & 66 & 83 \\
Kebutuhan Hidup Harian & 76 & 95 \\
Biaya Sekolah Anak & 51 & 64 \\
Bayar Hutang Pemberangkatan & 13 & 16 \\
Bayar Hutang Lainnya & 25 & 31 \\
\hline
\end{tabular}

Sumber: Analisis Data Primer (2012) 
Tabel 5. Besarnya Total Kirim Uang Remitan Buruh Migran

\begin{tabular}{ccccccccc}
\hline $\begin{array}{c}\text { Skor } \\
\text { remitan } \\
\text { (Juta } \\
\text { Rupiah) }\end{array}$ & \multicolumn{9}{c}{ Jumlah Responden Negara Tujuan } & Arab & Singapura & Taiwan & Malaysia & Kuwait & Korea & Jumlah \\
responden & $\begin{array}{c}\text { Persentase } \\
(\%)\end{array}$ \\
\hline$<20$ & 19 & 3 & 1 & - & 1 & - & 24 & 30,0 \\
$21-41$ & 16 & 2 & 2 & 4 & - & - & 24 & 30,0 \\
$42-62$ & 14 & 2 & 3 & 2 & - & 1 & 22 & 27,5 \\
$63-84$ & 1 & & - & - & - & - & 1 & 1,3 \\
$85-105$ & - & - & 3 & - & - & - & 3 & 3,8 \\
$>105$ & 5 & 1 & - & - & - & - & 6 & 7,5 \\
\hline JUMLAH & 55 & 8 & 9 & 6 & 1 & 1 & 80 & 100 \\
\hline
\end{tabular}

Sumber: Analisis Data Primer 2012

Standar gaji di Korea dan Taiwan adalah jauh lebih tinggi dibanding negara-negara lain seperti Arab Saudi, Singapura, Kuwait dan Malaysia, namun tidak selalu remitan buruh migran yang bekerja di Korea dan Taiwan remitannya lebih tinggi dari buruh migran yang bekerja di negara lainnya.

Dalam Tabel 5 terlihat total kiriman uang remitan menurut negara tujuan buruh migran bekerja. Besarnya total kirim remitan $<$ Rp 20 juta dengan negara tujuan Arab Saudi 19 responden, Singapura 3 responden, Taiwan 1 reponden, Kuwait 1 responden, dengan total jumlah responden 24 atau 30 persen. Besarnya total kirim remitan Rp 21 juta - Rp 41 juta dengan negara tujuan Arab Saudi 16 responden, Singapura 2 responden, Taiwan 2 reponden, Malaysia 4 responden, dengan total jumlah responden 24 atau 30 persen. Besarnya total kirim remitan Rp 42 juta - Rp 62 juta dengan negara tujuan Arab Saudi 14 responden, Singapura 2 responden, Taiwan 3 reponden, Malaysia 2 responden, dan Korea 1 responden dengan total jumlah responden 22 atau 27,5 persen. Besarnya total kirim remitan Rp 63 juta - Rp 84 juta dengan negara tujuan Arab Saudi 1 responden, dengan total responden 1 atau 1,3 persen total kirim remitan. Besarnya total kirim remitan Rp 85 juta - Rp 105 juta dengan negara tujuan Taiwan 3 responden, dengan total responden 3 atau 3,8 persen. Besarnya total kirim remitan $>106$ juta dengan negara tujuan Arab Saudi 5 responden dan Singapura 1 responden, dengan total responden 6 atau 7,5 persen.
Besarnya total kirim remitan yang dihasilkan oleh buruh migran ini berhubungan dengan pengelolaan remitan dalam keluarga buruh migran. Semakin besar uang remitan yang dikirimkan semakin besar kemungkinan untuk bisa berinvestasi. Keluarga buruh migran baru dapat berinvestasi bila semua kebutuhan yang mendesak sudah terpenuhi.

\section{KESIMPULAN}

Terdapat hubungan yang signifikan antara faktor internal dan eksternal keluarga buruh migran dengan kesediaan untuk berinvestasi. Macam investasi meliputi perusahaan, tanah, mobil, ternak dan rumah, sedangkan tabungan uang dan speda motor merupakan fungsi ganda dari macam investasi dan barang konsumtif. Hambatan yang dihadapi oleh keluarga buruh migran yaitu kebutuhan hidup harian, perbaikan rumah, biaya sekolah anak, hutang lain dan hutang pemberangkatan. Besarnya remitan berhubungan dengan kesediaan untuk berinvestasi yang didapat oleh buruh migran untuk masing-masing negara berbeda, karena standar pemberian gaji masing-masing negara tujuan, potongan biaya pemberangkatan, jangka waktu bekerja, dan jenis pekerjaan di Negara tujuan.

\section{DAFTAR PUSTAKA}

Budiyuwono, Nugroho. 1987. Pengantar Statistik Ekonomi dan Perusahaan. AMP YKPN. Yogyakarta. 
Halim, Abdul. 2009. Analisis Kelayakan Investasi Bisnis Kajian dari Aspek Keuangan. Edisi Pertama. Graha Ilmu. Yogyakarta.

Irianto, H. Agus. 2006. Statistik Konsep Dasar dan Aplikasinya. Cetakan Ketiga. Kencana Penada Media. Jakarta.

Primasanto, Teguh Adhi. 2010. Pengiriman Tenaga Kerja Terampil Indonesia ke Luar Negeri: Pembelajaran dari Filipina. Jurnal Diplomasi. Vol. 2 No. 1. Hal 187 189. http:isjd.pdii.lipi.go.id. Diakses tanggal 7 November 2011.
Subianto, Anwar. 2006. Pengaruh Pemanfaatan Remitan Buruh Migran Terhadap pertumbuhan Ekonomi Wilayah di Kabupaten Cilacap (Studi Kasus di kecamatan Adipala, Kecamatan Binangun dan Kecamatan Nusawangu). Tesis Pascasarjana Magister Teknik Pembangunan Wilayah dan Kota. Univesitas Diponegoro Semarang. Hal 1 dan 37. http:eprints.undip.ac.id. Diakses tanggal 7 November 2011.

Sukirno, Sadono. 1994. Pengantar Teori Mikroekonomi. Edisi Kedua. PT. Raja Grafindo Persada. Jakarta. 